Jurnal Ekonomi Syariah Teori dan Terapan p-ISSN: 2407-1935, e-ISSN: 2502-1508. Vol. 7 No. 6 Juni 2020: 1102-1117; DOI: 10.20473/vol7iss20206pp1102-1117

THE DETERMINANT ANALYSIS OF PROFITABILITY IN THE SHARIA BANKING INDUSTRY IN 2011-2018 USING AUTO REGRESIVE DISTRIBUTED LAG (ARDL) APPROACH ${ }^{1}$

\title{
ANALISIS DETERMINANT PROFITABILITAS PADA INDUSTRI PERBANKAN SYARIAH PERIODE 2011- 2018 PENDEKATAN AUTO REGRESIVE DISTRIBUTED LAG (ARDL)
}

\author{
Gita Martha Permatasari, Dian Filianti \\ Departemen Ekonomi Syariah - Fakultas Ekonomi dan Bisnis - Universitas Airlangga \\ martha.gita01@gmail.com*, dianfilianti@feb.unair.ac.id
}

\begin{abstract}
ABSTRAK
Penelitian ini bertujuan untuk mengetahui pengaruh Ekonomi Makro yaitu PDB dan Inflasi serta Karakteristik Bank yaitu CAR, FDR, NPF, BOPO dan Size terhadap Profitabilitas Industri Perbankan Syariah di Indonesia pada Periode 2011 - 2018. Data yang digunakan adalah data sekunder yaitu data triwulanan yang diperoleh dari lama resmi Bank Indonesia (www.bi.go.id), Badan Pusat Statistik (www.bps.go.id), dan laporan Statistik Perbankan Syariah yang dipublikasikan oleh OJK (www.ojk.go.id). Metode pengambilan sampel yang digunakan adalah metode purposive sampling. Teknik analisis menggunakan model ARDL (Autoregressive Distributed Lag) dengan alat statistik EViews 9. Hasil penelitian menunjukkan bahwa dalam jangka pendek Variabel PDB, Inflasi, BOPO, size berpengaruh signifikan terhadap profitabilitas Industri Perbankan Syariahdan Variabel CAR, FDR, NPF tidak berpengaruh signifikan terhadap profitabilitas Industri Perbankan Syariah. Sedangkan dalam jangka panjang Variabel $P D B, B O P O$, size berpengaruh signifikan terhadap profitabilitas Industri Perbankan Syariah dan Variabel Inflasi, CAR, FDR, NPF tidak berpengaruh signifikan terhadap profitabilitas Industri Perbankan Syariah
\end{abstract}

Kata Kunci: profitabilitas, bank syariah, ARDL

\section{ABSTRACT}

This study aims to determine the influence of the Macro Economy, namely GDP and Inflation and Bank Characteristics, namely CAR, FDR, NPF, BOPO and Size on the Profitability of the Sharia Banking Industry in Indonesia in the 2011 - 2018 Period. The data used are secondary data, namely quarterly data obtained from the official website of Bank Indonesia (www.bi.go.id), Badan Pusat Statistik (www.bps.go.id), and Statistik Perbankan Syariah reports published by OJK (www.ojk.go.id). The sampling method used was purposive sampling method. The analysis technique uses the ARDL (Autoregressive Distributed Lag) model with statistical tools EViews 9. The results of the study show that in the short term of the GDP, Inflation, BOPO, Size variables, they have a significant effect on the profitability of the Sharia Banking Industry and the CAR, FDR, NPF variables have no significant effect on profitability of Islamic Banking Industry. Meanwhile in the long run of the GDP, $B O P O$, Size variables, they have a significant effect on the profitability of the Sharia Banking Industry and the Inflation, CAR, FDR, NPF variable does not significantly influence the profitability

\footnotetext{
${ }^{1}$ Artikel ini merupakan bagian dari skripsi dari Gita Martha Permatasari, NIM: 041611433009, yang berjudul, "'pengaruh Ekonomi Makro dan Karakteristik Bank Terhadap Profitabilitas Industri Perbankan Syariah di Indonesia."
}

Informasi artikel

Diterima: 28-04-2020

Direview: $30-05-2020$

Diterbitkan: 15-06-2020

*Korespondensi

(Correspondence):

Gita Martha Permatasari

Open access under Creative Commons Attribution-Non

Commercial-Share A like 4.0

International Licence

(CC-BY-NC-SA) (CC) (-) 
of the Sharia Banking Industry.

\section{Keywords: Profitability, Sharia Bank, ARDL}

\section{PENDAHULUAN}

Industri perbankan mempunyai kedudukan berarti dalam pembangunan negara dan bertindak sebagai mediator antar mereka yang punya modal dan mereka yang memerlukan modal. Di negara Indonesia, metode perbankan yang diterapkan ialah metode perbankan ganda (dual banking system) yang mengoperasikan dua macam bisnis perbankan, yakni bank syariah dan bank konvensional. Oleh itu, prinsip yang diterapkan pemerintah melewati Bank Indonesia tentunya tidak sama bagi kedua macam bank. Bank syariah tak mengiktrikaf metode sukubunga, sehingga bank syariah mendapat keuntungan dari distribusi hasil pemeran usaha yang menerapkan bank dan investasi syariah. (Antonia,2001)

Dengan adanya perbankan syariah, umat Islam Indonesia dapat melakukan transaksi bank dengan aman tanpa khawatir akan riba. Setiap aktivitas lembaga keuangan Islam dipastikan tak ada yang menyimpang dari prinsip syariah sebab pada dasarnya lembaga keuangan islam memiliki filosofi menemukan keridhaan Allah S.W.T, untuk kemaslahatan baik didunia ataupun diakhirat. Oleh itu, bank syariah harus menghindari semua aktivitas yang mungkin menyimpang dari hukum islam Q.S Al-Baqarah ayat 275:

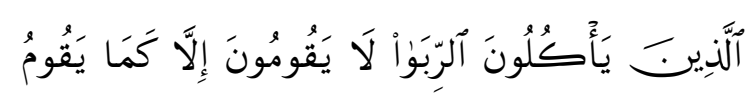

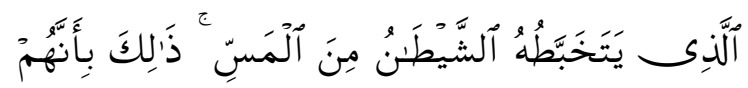

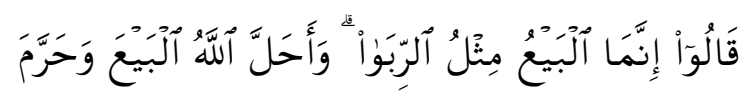

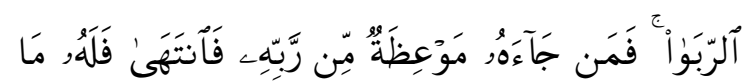

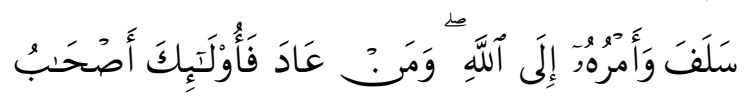

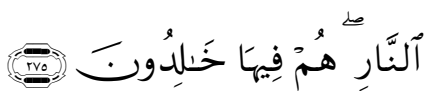
Artinya: "Orang-orang yang Makan (mengambil) riba tidak dapat berdiri melainkan seperti berdirinya orang yang kemasukan syaitan lantaran (tekanan) penyakit gila. Keadaan mereka yang demikian itu, adalah disebabkan mereka berkata (berpendapat), Sesungguhnya jual beli itu sama dengan riba, Padahal Allah telah menghalalkan jual beli dan mengharamkan riba. orang-orang yang telah sampai kepadanya larangan dari Tuhannya, lalu terus berhenti (dari mengambil riba), Maka baginya apa yang telah diambilnya dahulu[176] (sebelum datang larangan); dan urusannya (terserah) kepada Allah. orang yang kembali (mengambil riba), Maka orang itu adalah penghuni-penghuni neraka; mereka kekal di dalamnya."

Berdasarkan Undang-Undang Nomor 21 tahun 2008, Bank Syariah ialah bank yang melaksanakan aktivitas menurut aturan syariah, di mana ada beberapa macam jenis perbankan syariah yakni Bank Umum Syariah (BUS), 
Unit Usaha Syariah (UUS), dan Bank Pembiayaan Rakyat Syariah (BPRS).

Tabel 1.

Jumlah Perbankan Syariah Tahun 2011-2018

\begin{tabular}{|c|c|c|c|c|c|c|c|c|}
\hline \multirow{2}{*}{ Indikator } & \multicolumn{8}{|c|}{ Tahun } \\
\hline & 2011 & 2012 & 2013 & 2014 & 2015 & 2016 & 2017 & 2018 \\
\hline $\begin{array}{l}\text { BankUmum } \\
\text { Syaria }\end{array}$ & 11 & 11 & 11 & 12 & 12 & 13 & 13 & 14 \\
\hline $\begin{array}{l}\text { Unit Usaha } \\
\text { Syariah }\end{array}$ & 24 & 24 & 23 & 22 & 22 & 21 & 21 & 20 \\
\hline $\begin{array}{l}\text { Bank } \\
\text { Pembiayaan } \\
\text { Rakyat } \\
\text { Syariah } \\
\end{array}$ & 155 & 158 & 163 & 163 & 163 & 166 & 167 & 167 \\
\hline
\end{tabular}

Berdasarkan tabel 1, bank syariah di Indonesia kian berkembang. Ini bisa diperhatikan dari banyaknya Bank Umum Syariah yang meningkat pada tiap tahunnya. Peningkatan jumlah BUS tak diikuti dengan peningkatan jumlah Unit Usaha Syariah (UUS). Menurunnya UUS disebabkan oleh spin/off dari UUS ke BUS. Sedangkan BPRS tiap tahunnya mengalami fluktuasi/naik turun.

Sebagai institusi ekonomi yang penting, ada pemantauan kinerja yang yang dilakukan oleh lembaga pengawas bank. Untuk menilaii kinerja keuangan bank, dapat ditinjau dari tingkat profitabilitas bank, berkaitan dengan seberapa baik kinerja bank dalam melakukan bisnisnya. Profitabilitas dapat dilihat dari membandingkan keuntungan yang didapat melalui total aset atau modal. Kian tinggi profitabilitas bank, kian bagus pengembalian bank. Indikator terbaik untuk mengevaluasi kinerja bank ialah profitabilitas. (Hasibuan, 2007:100).

Indikator yang digunakan untuk menilai menilai tingkat profitabilitas meliputi rasio ROE yang menunjukkan jumlah pengembalian laba atas modal, dan rasio ROA yang menunjukkan kemampuan semua aset yang dipakai guna menerima profit. Untuk mempertimbangkan kestabilan bank, Bank Indonesia memprioritaskan profitabilitas ROA dibandingkan ROE, sebab Bank Indonesia memprioritaskan hasil profitabilitas bank yang dinilai menggunakan aset dominan banyak bersumber dari tabungan nasabah, oleh karena itu ROA lebih menunjukkan profitabilitas bank. Kian besar pengembalian bank atas aset, kian banyak laba yang diterima bank, sehingga kian bagus posisi bank dalam penerapan aset (Dendawijaya,2005).

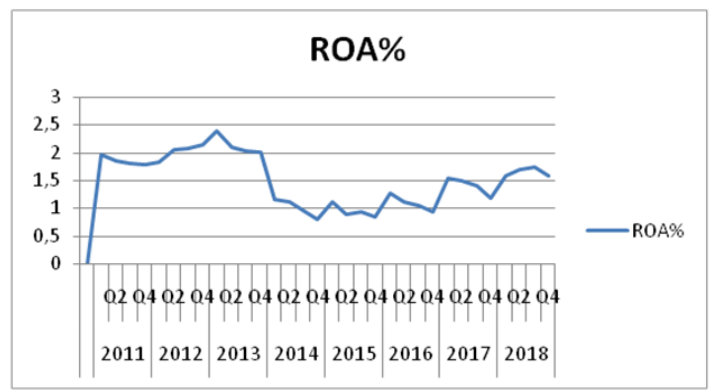

Gambar 1.1

Rasio ROA tahun $2011-2018$ Sumber :Statistik Perbankan Syariah (diolah untuk penelitian)

Sumber: Statistik Perbankan Syariah Gambar 1. Rasio ROA tahun 2011-2018

Pada gambar grafik di atas profitabilitas perbankan syariah di 2011 hingga 2018 menunjukan bahwa grafik mengalami perubahan setiap tahunnya. Profitabilitas mengalami perubahan yang signifikan di tahun 2013 dan penurunan paling rendah terjadi di tahun 2014.

Menurut Rivai (2009:76) dan Haron (2004), tingkat profitabilitas dapat dipengaruhi oleh ekonomi makro dan rasio kinerja kevangan bank syariah. Sukirno (2006:26) mengatakan bahwasanya unsur ekonomimakro serupa 
neraca pembayaran, perolehan nasional mencakup produk domestik bruto dan produk nasional bruto, tingkat pertumbuhan ekonomi, tingkat inflasi, dan lain-lain bisa memberi pengaruh tingkat profitabilitas bank syariah. Ramlall (2009) mengatakan bahwa salah satu unsur yang bisa memberi pengaruh tingkat profitabilitas bank syariah yakni karakteriistik bank yaitu CAR, FDR, NPF, BOPO, dan Size.

Terkait dengan Profitabilitas Industri Perbankan Syariah, peneliti akan mengambil tujuh variabel yang akan diuji dampaknya kepada tingkat profitabilitas, yaitu Produk Domesti Bruto (PDB), Inflasi,Capital Adequacy Ratio (CAR),Financing to Deposiit Ratio (FDR),Non Performing Finance (NPF), Biaya Operasional dan Pendapatan Operasional (BOPO), dan Ukuran Bank (Size).

Produk Domestik Bruto (PDB) ialah tolak ukur suatu negara dari kegiatan ekonomi nasionalnya. Pertumbuhan ekonomi bisa diistilahkan sebagai pertumbuhan pendapataan nasional pada suatu negara yang terjadi dari satu tahun ke tahun selanjutnya. Dengan adanya peningkatan jumlah pekerja, sumber daya alam, dan teknologi canggih juga bisa memberi pengaruh pertumbuhan ekonomi pada suatu negara (Sukirno 2005:178). Penelitian Amirus Sodiq (2015) mengungkapkan PDB memiliki pengaruh positive significant kepada profitabilitas Bank Syariah, bersamaan atas adanya peningkatan kesejahteraan masyarakat menyebabkan pendapatan akan meningkat dan diikuti dengan peningkatan tabungan yang dimiliki pada bank-bank syariah.

Inflasi ialah unsur ekonomi makro yang memiliki dampak kuat kepada perekonomian negara. Inflasi yang naik akan berakibat naiknya harga barang dan jasa, sehingga berdampak pada sumber profit bank sebab masyarakat mengalokasikan hartanya untuk mencukupi pengeluaran. Sehingga, inflasi akan mempengaruhi profitabilitas bank. Pada penelitian Sodiq (2015) mengungkapkan Inflasi memiliki pengaruh negative dan significant kepada profitabilitas. Dan pada penelitian Sahara (2013) mengungkapkan inflasi berpengaruh signifikan kepada profitabilitas.

Rasio yang diterapkan untuk menghitung atau melihat kecukupan modal yang dipunyai bank dalam menyokong aset beresiko disebut Capital Adequacy Ratio (CAR). Dalam penelitian Fitri Zulifiah dan Joni Susilowibowo (2014) mengungkapkan bahawa CAR memiliki dampak positive dan signifkan kepada Profitabilitas Bank Syariah hasil penelitihan menerangkan bahwa CAR yang sehat dan menurut ketetapan Bank Indonesia yakni minimal $8 \%$, yang berarti bank sanggup membiayai aktivitas operasi bank dan memberi kontribusi yang besar bagi profitabilitas suatu bank.

$$
\text { Rasio yang diterapkan guna }
$$
menilai kecairan bank yang mencerminkan kemampuan bank untuk 
mencukupo keperluan kreditnya kredit adalah dengan mengenakan nilai / jumlah aset yang disebut Nisbah Pembiayaan ke Deposit (Dendawijaya, 2003).Dalam penelitian Medina dan Rina (2018) mengungkapkan bahwa FDR memiliki pengaruh positive significant kepada profitabilitas Bank Syariah, di mana bank sanggup melakukan fungsi FDR dengan bagus sebab memberikan penyaluran pembiayaan.

\section{Pembiayaan bermasalah dan} kemungkinan atau berpeluang tak sanggup untuk mengembalikan pembiayaan menurut persyaratan yang sudah disepakati disebut dengan Non Performing Financing (NPF). Berdasarkan Djamil (2012:66) dalam Rani (2013) NPF ialah pembiayaan bermasalah mulai dari yang kurang lancar hingga macet. NPF merupakan cerminan resiko kredit, jika pada suatu bank memiliki NPF kecil, pihak bank akan menanggung resiko kredit yang kecil (Nusantara,2009) begitupula dengan sebaliknya, apabila suatu bank memiliki NPF besar, pihak bank akan menanggung resiko kredit yang besar.

Rasio yang diterapkan guna menilai atau menghitung tingkat efiisiensi dan kesanggupan bank dalam menyokong aktivitas operasional dapat dihitung memakai Beban Operasional dan Pendapatan Operasional. Jika suatu bank mempunyai nilai BOPO tinggi, akan mengakibatkan performa manajemen bank menurun. Demikian pula sebaliknya, apabila nilai rasio BOPO rendah berarti performa manajemen semakin bagus
(Riyadi, 2006). Penelitian yang dilaksanakan oleh Omar Masood (2012) mengungkapkan bahwa BOPO memilik pengaruh negative significant kepada profitabilitas Bank Syariah.

Size ialah skala yang dibuat untuk melihat ukuran besar atau kecilnya sebuah bank dengan sebuah bank dengan mengetahui total aktiva. Kian besar ukuran bank berarti kian besar pula harta yang dipunyai perusahaan. Dengan besarnya ukuran bank dapat berguna untuk mempermudah perusahaan meyakinkan pemodal dalam mendapatkan dana. Dalam penelitian Alharbi (2017) memperlihatkan bahwa size memiliki pengaruh positive significant kepada Profitabilitas Bank Syariah.

\section{Rumusan Masalah}

Dimana yang membedakan penelitihan ini dengan penelitihan terdahulu ialah berada pada variabel dan jangka waktu penelitian sehingga bisa ditemukan rumusan masalah pada penelitihan ini sebagai berikut:

1. Apakah PDB, Inflasi, CAR, FDR, NPF, BOPO, dan Size berpengaruh secara parsial terhadap Profitabilitas Industri Perbankan Syariah periode 2011 2018?

2. Apakah PDB, Inflasi, CAR, FDR, NPF, BOPO, dan Size berpengaruh secara simultan terhadap Profitabilitas Industri Perbankan Syariah periode 2011 2018?

\section{Tujuan Penelitihan}

Tujuan dilakukan penelitihan ini ialah untuk menganalisa Pengaruh 
PDB,Inflasi, CAR, FDR, NPF, BOPO, dan Size terhadap Profitabilitas Industri Perbankan Syariah pada periode 2011-2018. Selain itu, penulis penelitihan ini bertujuan untuk mengenal dampak PDB,Inflasi, CAR, FDR, NPF, BOPO, dan Size terhadap profitabilitas Industri Perbankan Syariah, secara simultan dan parsial.

\section{LANDASAN TEORI DAN PENGEMBANGAN HIPOTESIS}

Tahun 2008 dalam Undangundang Nomor 21 tertulis pengertian mengenai perbankan syariah, Bank ialah badanusaha yang menggabungkan dana dari rakat dalam wujut simpan dan menyalurkann terhadap masyarakat dalam wujut credit maupun yang lainnya guna menaikan standar kehidupan masyarakat. Bank yang di dalam menjalankan bisnisnya berdasarkan hukum dan prinsip syariah disebut dengan Bank Syariah. Secara umum fungsi bank syariah dan bank konvensional tidak memiliki selisish jauh. Fungsi bank syariah sebagai manager investasi, yakni menghimpun dana dari pemberi modal atau nasabahnya berlandaskan prinsip mudharabah (bagi hasil). Fungsi bank syariah sebagai investor, yakni melaksanakan penyaluran dana melewati aktivitas investasi berlandaskan prinsip bagi hasil, jual beli atau sewa. Fungsi bank syariah sebagai penyedia jasa perbankan, yakni menyajikan layanan transfer, kliring, inkaso. Yang membedakan yakni dalam penerapannya menerapkan prinsip-prinsip syariah.

\section{Profitabilitas Perbankan Syariah}

Berdasarkan Harahap (2009:309) profitabilitas ialah mengilustrasikan kesanggupan perusahaan menerima laba melewati segala aktivitas bisnisnya. Untuk menjaga aliran sumber modal dibutuhkan pengembalian yang layak. Sebuah indikator untuk mengukur efektivitas dan kesanggupan bank dalam menciptakan laba, bisa menerapkan teknik analisa profitabilitas yang mengkaitkan antar pospos tertentu di dalam laporan laba rugi. Oleh sebab itu, teknik analisa ini bisa dibilang analisa laporan laba rugi.

\section{Ekonomi Makro}

\section{Produk Domestik Bruto}

Produk Domestik Bruto ialah seluruh pelayananjasa dan produk yang diproduksi oleh warganegara (warganegara asing) pada tempo tertentu di suatu negara, umumnya dalam tempoh setahun (Soebagyo, 2013: 66), perincian PDB dalam suatu negara tak cuma terukur dalam nominal suatu barang dan jasa yang dihasilkan perusahaan milik warganegara, tapi oleh warga asing yang ada di dalam kawasan. Aktivitas oprasional yang dijalankan oleh perusahaan multinasional ikut serta menunjang income ekonomi negara lewat peningkatan aktivitas produksi atas barang dan jasa, penggunanan tenagakerja dan menyokong aktivitas eksport.

\section{Inflasi}

Bank Indonesia menjabarkan inflasi ialah kecondongan naiknya tingkat harga secara signifikan. Berdasarkan Samuelson 
dan Nordhaus (1993:293) terjadinya peningkatan harga serta barang-barang modal dapat diartikan inflasi. Inflasi ialah dimana saat harga cenderung mengalami kenaikan secara berkepanjangan (Boediono, 2004:161). Indikator laju inflasi ialah Indeks Harga Konsumen (IHK).

\section{Karakteristik Bank}

\section{Capital Adequacy Rasio (CAR)}

Capital Adequacy Rasio ialah cukupan modal yang dipunyai bank, dan kesanggupan management bank untuk mengenali, menilai, menstandarisasi dan mengendalikan resko yang mampu mempengaruhi jumlah atau total modal.

\section{Financing to Deposit Ratio (FDR)}

Financing to Deposit Ratio (FDR) Berdasarkan Dendawijaya (2009) Rasio yang diterapkan guna menilai likuiditas bank yang memperlihatkan daya bank dalam mencukupi keinginan kredit dengan mengenakan jumlah/total aset disebut dengan Financing to Deposit Ratio. Sementara itu, berdasarkan Kasmir (2012: 319), Financing to Deposit Ratio ialah laporan guna menilai komposiisi jumlah credit yang diberi diperbandingkan jumlah dana nasabah dan modal sendiri yang dipakai.

\section{Non Performing Financing (NPF)}

Non Performing Financing (NPF) Pembiayaan bermasalah dan kemungkinan atau berpeluang tak sanggup untuk mengembalikan pembiayaan menurut persyaratan yang sudah disepakati disebut dengan Non Performing Financing (NPF). Untuk melihat kwalitas kredit atau pembiayaan dari suatu bank dapat dilihat besaran dari NPF. Biaya Operasional terhadap Pendapatan Operasional (BOPO)

BOPO termasuk rasio rentabilitas (earnings). Rasio yang diterapkan guna menilai atau menghitung tingkat efiisiensi dan kesanggupan bank dalam menyokong aktivitas operasional dapat dihitung memakai Beban Operasional dan Pendapatan Operasional. Jika suatu bank mempunyai nilai BOPO tinggi, akan mengakibatkan performa manajemen bank menurun. Demikian pula sebaliknya, apabila nilai rasio BOPO rendah berarti performa manajemen semakin bagus (Riyadi, 2006).

\section{Ukuran Perusahaan (Size)}

Size ialah skala yang dibuat untuk melihat ukuran besar atau kecilnya sebuah bank dengan sebuah bank dengan mengetahui total aktiva. Biasanya Size dibagi menjadi tiga kelompok, yakni usaha kecil, usaha sederhana dan usaha besar. Penentuan langkah ini ialah menurut jumlah aset usaha yang bisa ditetapkan menurut jumlah penjualan, jumlah aset,dan rata-rata penjualan (Stiawan 2009).

\section{Hubungan Antar Variabel}

\section{Hubungan PDB terhadap Profitabilitas}

Produk Domestik Bruto (PDB) ialah tolak ukur suatu negara dari kegiatan ekonomi nasionalnya. Unsur-unsur yang terkait dengan pasokan, permintaan, credit, dan deposiito dapat memberi pengaruh PDB. 
Permatasari, et al/Jurnal Ekonomi Syariah Teori dan Terapan Vol. 7 No. 6 Juni 2020: 1102-1117

Pada penelitihan Sahara (2013) dan Sodiq (2015) mengungkapkan PDB memiliki dampak positive signifkan terhadap profitabiilitas bank syariah. Berdasarkan Madura (2007:122) mengilustrasikan bahwa saat PDB meningkat pada suatu negara memperlihatkan bahwa kesejahteraan masyarakat juga meningkat, adanya naiknya kesejahteraan rakyat akan diiikuti dengan naiknya tabungan masyarakat pada bank-bank,dan juga akan berdampak positive kepada pendapatan bank yang akan menaikkan ROA bank syariah.

\section{Hubungan Inflasi terhadap Profitabilitas}

Berdasarkan Madura (2007: 157), inflasi memberi pengaruh terhadap performa perusahaan sebab dapat memengaruhi perolehan dan pengeluaran perusahaan. Jika terjadi kenaikan harga secara terus menerus dapat disebut dengan inflasi. Dan apabila terjadi inflasi yang tinggi mengakibatkan kondisi ekonomi tak seimbang

Dalam penelitian oleh Masood (2012) dan Khizer Ali (2011) mengatakan inflasi memiliki dampak negative signifkan terhadap profitabilitas bank syariah. Dengan fenomena ini memperlihatkan bahwa jika terjadi inflasi pada suatu negara mengakibatkan minat penduduk untuk berinvestasi atau menabung, dan memproduksi suatu barang akan berkurang, maka mampu menurunkan profitabilitas suatu bank.

\footnotetext{
Hubungan Capital Adequacy Ratio (CAR) terhadap Profitabilitas
}

Capital Adequacy Ratio memperlihatkan total keseluruhan aktivitas perbankan yang mengandung risiko (pinjaman, investasi, sekuritas, kredit dengan bank lain). Dalam penelitian Widyaningrum (2014) dan Stiawan (2009), CAR memiliki dampak positive significant terhadap ROA bank syariah.

Capital Adequacy Ratio ialah ukuran yang sangat penting dari kesehatan bank dan mendapatkan perhatian optimal dari pemodal bank. Berdasarkan teori, kian tinggi CAR (sesuai dengan peraturan BI), kian besar kesanggupan bank dalam menanggung risiko kredit berisiko/aktivitas produktif. CAR yang lebih tinggi akan mempunyai dampak positif pada profitabilitas bank.

Hubungan Financing to deposit ratio (FDR) terhadap Profitabilitas

Berdasarkan Kasmir (2012:221)
Loan to Deposit Ratio jika didalam
perbankan syariah dikenal dengan istilah
Financing to Deposit Ratio dapat dipakai
untuk mengukur kesanggupan bank
dalam memenuh kewajiban
jangkapendek ketika ditagih.
Dalam penelitian Widyaningrum (2014) dan Stiawan (2009) bahwa FDR memiliki dampak positive significant terhadap profitabilitas. FDR dipakai untuk menilai likuiditas bank dengan membandingkan total kredit yang diberi bank kepada dana pihak ketiga. Kian menjulang FDR, kian besar dana yang didistribusikan ke dana pihak ketiga. Dengan distribusi dana pihak ketiga yang besar, pendapatan bank (ROA) akan 
meningkat, sehingga FDR berdampak positive pada Profitabilitas (ROA) bank syariah.

\section{Hubungan Non Performing Financing (NPF) terhadap Profitabilitas}

NPF ialah jumlah pembiayaan bermasalah dan kemungkinan tak bisa ditagih, yang nantinya akan menjadi risiko pembiayaan (Almunawwaroh dan Marliana, 2018). Rasio NPF yang tinggi menampakkan kwalitas buruk dari pembiayaan bank syariah sebab kredit macet yang menurunkan pendapatan bank sehingga bisa mengganggu profitabilitas bank (Wibowo dan Syaichu, 2013).

Risiko kredit yang dinilai dengan NPF memiliki pengaruh negative kepada performa keuangan bank yang dinilai dengan profitabiltas. Oleh sebab itu, apabila NPF lebih tinggi, profitabilitas bank akan menurun, yang memiliki arti bahwa performa keuangan bank merosot.Sebaliknya, apabila NPF menurun, profitabilitas akan meningkat, sehingga performa keuangan bank dapat dibilang membaik. Pada penelitian Masood (2012) dan Almunawwaroh (2018) bahwa NPF memiliki dampak negative terhadap ROA bank syariah.

\section{Hubungan Biaya Operasioanl dan Pendapatan Operasional (BOPO)
(1) terhadap Profitabilitas}

Rasio yang diterapkan guna menilai atau menghitung tingkat efiisiensi dan kesanggupan bank dalam menyokong aktivitas operasional dapat dihitung menggunakan Beban
Operasional dan Pendapatan Operasional. Jika suatu bank mempunyai nilai rasio BOPO tinggi, akan mengakibatkan performa manajemen bank menurun. Demikian pula sebaliknya, apabila nilai rasio BOPO rendah berarti performa manajemen semakin bagus (Riyadi, 2006). Hal ini didukung oleh penelitihan Siswantoro (2014) dan Lemiyana yang mengungkapkan BOPO memiliki dampak negative significant terhadap ROA dan bank syariah.

Hubungan Ukuran perusahaan (SIZE) terhadap Profitabilitas

Size bisa mempengaruhi kesanggupan bank dalam mendatangkan laba. Pada dasarnya perusahaan besar yang menyimpan total aktiva tinggi sanggup membikin profit tinggi pula. Kian tinggi asset pembiayaan yang disalurkan akan kian tinggi yang nantinya bisa memberikan profit bagi bank. Jika profit naik profitabilitas bank juga akan naik. Pada penelitian Smaoui dan Salah (2012), Bukhair (2013) menjelaskan Size memiliki dampak positive significant terhadap ROA bank syariah.

\section{Hipotesis}

$\mathrm{H}_{1}$ : Produk Domestik Bruto (PDB) berpengaruh positive signifikan terhadap ROA dalam jangka pendek dan jangka panjang.

$\mathrm{H}_{2}$ : Inflasi berpengaruh negative signifikan terhadap ROA dalam jangka pendek dan jangka panjang.

$\mathrm{H}_{3}$ : Capital Adqucy Ratio (CAR) berpengaruh positive signifikan 
terhadap ROA dalam jangka pendek dan jangka panjang.

$\mathrm{H}_{4}$ : Financing to deposit ratio (FDR) berpengaruh positive signifikan terhadap ROA dalam jangka pendek dan jangka panjang.

$\mathrm{H}_{5}$ : Non Performing Financing (NPF) berpengaruh negative signifikan terhadap ROA dalam jangka pendek dan jangka panjang.

$\mathrm{H}_{6}$ : Biaya Oprasioanl dan Pendpatan Oprasional (BOPO) berpengaruh negative signifikan terhadap ROA dalam jangka pendek dan jangka panjang.

$\mathrm{H}_{7}$ : SIZE berpengaruh positive signifikan terhadap ROA dalam jangka pendek dan jangka panjang.

$\mathrm{H}_{8}$ : PDB, Inflasi, CAR, FDR, NPF, BOPO, SIZE, berpengaruh secara simultan terhadap ROA dalam jangka pendek dan jangka panjang.

\section{METODE PENELITIAN}

\section{Pendekatan Penelitian}

Penelitihan ini mengaplikasikan pendekatan kuantitative. Penelitihan kuantitative ialah penelitihan dilakukan untuk menanggapi masalah melalui teknik pengukuran yang akurat terhadap variabel tertentu untuk menghasilkan kesimpulan yang dapat digeneralisasi (Abdurrahman Misno, 2018: 19).

\section{Jenis dan Sumber Data}

Data yang dipakai dipenelitihan ini ialah data sekunder. Data ini didapatkan dalam bentuk yang telah diselesaikan dan telah dikumulkan lalu di olah dengan pihak lain (Suryani dan Hendrayadi,
2016:171). Data sekunder yang dipakai ialah data timeseries (runtun waktu data) ialah triwulan data yang didapatkan dari sumber resmi Bank Indonesia (www.bi.go.id), Badan Pusat Statistik (www.bps.go.id) dan penjelasan Statistik Perbankan Syariah yang dipublikan OJK (www.ojk.go.id). Data sekunder penelitihan ini mencakup Produk Domestik Bruto (PDB), Inflasi, Capital Adequacy Ratio (CAR), Financing Deposit Ratio (FDR), Non Performing Financing (NPF), Biaya Oprasional dan Pendapatan Oprasional (BOPO) dan Ukuran Bank (Size).

\section{Model Empiris}

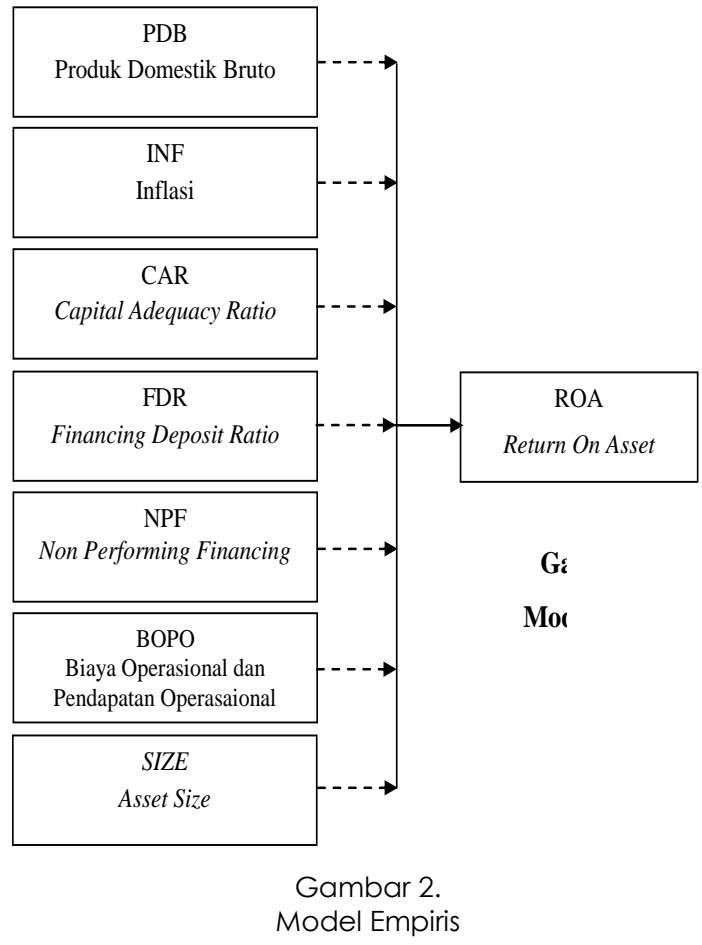

Populasi dan Sampel

Populasi ialah area penyamarataan yang terdiri dari obyek atau subjek dengan sejumlah ciri khusus yang diaplikasikan oleh peneliti guan dipelajari kemudian diringkas (Sugiyono, 2015:62). Populasi didalam penelitihan ini 
ialah Industri Perbankan Syariah di Indonesia.

Sampel ialah beberapa komponen bilangan dan ciri yang dipunya oleh populasi (Sugiyono, 2015:63). Pengambilan sample dalam penelitihan ini ialah memakai salah satu teknik pada nonprobability sampling yakni memakai purposive sampling. Purposive sampling ialah teknik sampling menggunakan kriteria yang sudah dipilih oleh peneliti dalam memilih sampel (Abdurrahman dan Ahmad, 2018:117).

\section{Teknik Analisis}

\section{Statistik Deskriptif}

Dalam menganalisa data penelitian ini dipakai metode statistiik deskriiptif. Fungsi statistik deskriptive ialah untuk memberikan tinjauan kepada topik yang akan di teliti lewat data sample atau populasi tanpa bermaksud mengerjakan analisa dan membikin simpulan yang berlaku umum (Sugiyono, 2016:21). Statistik deskriptif juga dipakai untuk mengenal nilai dari variabele independent dan variable dependent, yang berikutnya diberikan penjelasan bagaimana variable independent memberi pengaruh variabel terikat sehingga bisa ditarik simpulan dari hubungan antar variabel. Teknik pengolahan data memakai perhitungan komputasi program E-Views 9, yakni suatu aplikasi computer statistik yang sanggup mengolah data statistik akurat, menjadi berbagai output yang dikehendakii para pengambiil keputusan. Selain itu, E-Views 9 adalah versi terkini telah mempunyai pilihan Autoregressive Distributed Lag, yakni metode yang akan diterapkan dalam penelitian ini.

\section{Auto Regressive Distributed Lag (ARDL)}

ARDL ialah methode regresi yang melibatkan lag dari dua variable dependent dan independent secara berbarengan. Dengan menerapkan model ini, kita bisa mengkaji prospek jangkapanjang saat variable penjelas campuran antara yang berkarakter I (1) dan I (0). Estimator ARDL akan menjadikan koefiisien jangkapanjang yang konsistent. Salah satu kelebihan dari model ARDL ialah menjadikan estimasi yang konsistent dengan koefisient jangkapanjang yang baik terlepas dari apakah variable penjelas atau regresornya ialah I (0) atau I (1). Dalam kasus adanya hubungan jangkapanjang yang bersifat trendstationarity, dengan ARDL bisa dilaksanakan detrending kepada series dan dimodelkan detrended series serupa distributed lag yang stasioner (Falianty, 2003).

\section{HASIL PEMBAHASAN}

Menurut hasil penelitihan, dapat diketahui skor minimal, maksimal, rata-rata dan standar deviasi dari tiap-tiap variable yang diaplikasikan dalam periode waktu penelitihan triwulan. Pada triwulan I 2011 hinga triwulan 2018 pada tabel dibawah ini.

Tabel di bawah menampilkan bahwa terdapat 32 data observasi. ROA mempunyai skor terendah 0.008020 dan skor tertinggi 0.023860 dengan rata-rata sebesar 0.015124. GDP mempunyai skor terendah 14.37440 dan skor tertinggi 
14.80288 dengan rata-rata sebesar 14.59827.

Tabel 2.

Deskripsi Statistik Variabel

\begin{tabular}{lccccc}
\hline & Mean & Median & Min & Max & Std. Dev. \\
\hline ROA & 0.015124 & 0.015585 & 0.008020 & 0.023860 & 0.004604 \\
LN_GDP & 14.59827 & 14.59682 & 14.37440 & 14.80288 & 0.120380 \\
INFLASI & 0.050334 & 0.045450 & 0.031600 & 0.086100 & 0.016996 \\
CAR & 0.160831 & 0.160100 & 0.140900 & 0.212500 & 0.018794 \\
FDR & 0.935797 & 0.926800 & 0.843200 & 1.044300 & 0.062533 \\
NPF & 0.036550 & 0.037300 & 0.022200 & 0.050500 & 0.008213 \\
BOPO & 0.838800 & 0.844900 & 0.717600 & 0.943800 & 0.073027 \\
LN_SIZE & 12.46539 & 12.52640 & 11.52475 & 13.10697 & 0.439445 \\
Observations & 32 & 32 & 32 & 32 & 32 \\
\hline \multicolumn{2}{c}{ Sumber: Data Diolah } & & & &
\end{tabular}

Inflasi mempunyai skor terendah 0.031600 dan skor tertinggi 0.086100 dengan rata-rata sebesar 0.050334. CAR mempunyai skor terendah 0.140900 dan skor tertinggi 0.212500 dengan rata-rata sebesar 0.160831. FDR mempunyai skor terendah 0.843200 dan skor tertinggi 1.044300 dengan rata-rata sebesar 0.935797. NPF mempunyai skor terendah 0.022200 dan skor tertinggi 0.050500 dengan rata-rata sebesar 0.036550. BOPO mempunyai skor terendah 0.717600 dan skor tertinggi 0.943800 dengan rata-rata sebesar 0.838800. Size mempunyai skor terendah 11.52475 dan skor tertinggi 13.10697 dengan rata-rata sebesar 12.46539 .

\section{Hasil Analisis}

Uji Stasioneritas Data (Unit Root Test)

Tabel 3. Hasil Uji Root test (Uji Stasioneritas)

\begin{tabular}{|c|c|c|c|c|c|}
\hline \multirow[t]{2}{*}{ No. } & \multirow[t]{2}{*}{ Variabel } & \multicolumn{2}{|c|}{$\begin{array}{l}\text { Augmented Dickey- } \\
\text { Fuller (ADF) }\end{array}$} & \multicolumn{2}{|c|}{ Phillips Perron } \\
\hline & & at level & $1^{\text {It difference }}$ & at level & $I^{I I}$ difference \\
\hline 1. & ROA & 0.4123 & $0.0000^{*}$ & 0.4280 & $0.0000^{*}$ \\
\hline 2. & LN_GDP & 0.7171 & $0.0001^{*}$ & 0.6327 & $0.0000^{*}$ \\
\hline 3. & INFLASI & 0.1636 & $0.0027^{*}$ & 0.2700 & $0.0034^{*}$ \\
\hline 4. & CAR & 0.8746 & $0.0000^{*}$ & 0.8837 & $0.0000^{*}$ \\
\hline 5. & BOPO & 0.5861 & $0.0000^{*}$ & 0.1609 & $0.0000^{*}$ \\
\hline 6. & LN SIZE & $0.0240^{*}$ & $0.0031^{*}$ & $0.0109^{*}$ & $0.0037^{*}$ \\
\hline 7. & FDR & 0.6518 & $0.0001^{*}$ & 0.7061 & $0.0001^{*}$ \\
\hline 8. & NPF & 0.6617 & $0.0001^{*}$ & 0.6389 & $0.0001^{*}$ \\
\hline
\end{tabular}

Penelitian ini mengaplikasikan sistem ADF dan Phillips-Perron untuk melihat stasioneritas data.Hasil pengujian
Unit Root dengan mengaplikasikan Eviews9 dibuktikan pada Tabel 3.

Menurut Menurut uji unit root diatas, satu variable (LN_Size) stasioner pada tingkatan (at level) cocok mengaplikasikan model Augmented Dickey-Fuller (ADF) ataupun Phillips Perron. Adajuga variable ROA, LN_GDP, Inflasi, CAR,BOPO,FDR, dan NPF stasioner pada first difference. Hal yang demikian dibuktikan oleh skor probabilitas yang lebih dominan dari a (5\%). Sebab delapan variable stationer pada first difference dan satu variable stationer dilevel (at level), sehingga analisa yang bisa diaplikasikan pada model yang demikian yakni mengaplikasikan model ARDL (Autoregressive Distributed Lag).

\section{Penentuan Lag Optimal}

Ada juga nilai lag length criteria yang diaplikasikan pada estimation ini yakni lag 2.

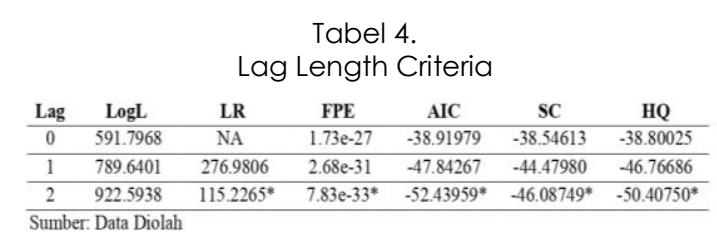

Uji Diagnosis Model ARDL

Tabel 5. ARDL Bound Test

\begin{tabular}{ccc}
\hline Test Statistic & Value & K \\
\hline F-statistic & 4.407563 & 7 \\
\hline \multicolumn{4}{l}{ Critical Value Bounds } \\
\hline Significance & I0 Bound & I1 Bound \\
\hline $10 \%$ & 2.03 & 3.13 \\
$5 \%$ & 2.32 & 3.5 \\
$2.5 \%$ & 2.6 & 3.84 \\
$1 \%$ & 2.96 & 4.26 \\
\hline \multicolumn{3}{l}{ Sumber: Data Diolah }
\end{tabular}

Ini memperlihatkan hasil etimasii ARDL dapat diaplikasikan sampai signifikation $a=1 \%$, hasil ini juga memperlihatkan bahwa antar variable 
Permatasari, et al/Jurnal Ekonomi Syariah Teori dan Terapan Vol. 7 No. 6 Juni 2020: 1102-1117

mempunyai relasi kointegrasi jangkapanjang.

Selain ARDL Bound Test,hasil lainnya perlu dikaji yakni skor errorcorrelation coefficient (CointEq(-1)) pada model jangkapendek ECM. Skor ini menampilkan beberapa banyak error yang akan diperbaiki ditiap jangka waktu. Supaya mencukupi syarat, skor ini diharuskan negative dan significant. Tabel 6 menampilkan bahwa skor CointEq(-1) ini yakni -0.766542 dengan probability 0.0357 , hasilnyanya negative dan significant sperti yang diinginkan. Ini menampilkan bahwa $766 \%$ error pada data akan diperbaiki pada tiap jangka waktu.

Tabel 6.

Error-Correlation Coefficient

\begin{tabular}{ccccc}
\hline Variable & $\begin{array}{c}\text { Coefficien } \\
\text { t }\end{array}$ & Std. Error & t-Statistic & Prob. \\
\hline CointEq(-1) & -0.766542 & 0.323968 & -2.366102 & 0.0357 \\
\hline Sumber: Data Diolah & & & &
\end{tabular}

\section{Analisis Jangka Pendek ECM}

Hasil jangkapendek modell ARDL bisa diperhatikan dari ECM-nya. ECM ini didapat dengan mengaplikasikan sistem general to specific yang dimulai lag maksimum lalu ketentuan percobaan standart mengeliminasi variable-variable ARDL secara spesifik tak significant, sampai mendapatkan hasil paling simple (parsimonious regression).

Tabel 7.

Hasil Estimasi Jangka Pendek

\begin{tabular}{|c|c|c|c|c|}
\hline Variabel & Coefficient & Std. Error & t-Statistic & Prob. \\
\hline LN GDP & 6.002481 & 0.281140 & 21.350493 & $0.0000^{*}$ \\
\hline INFLASI & 0.097217 & 0.051083 & 1.903126 & $0.0813^{* *}$ \\
\hline CAR & 0.000440 & 0.051865 & 0.008492 & 0.9934 \\
\hline FDR & 0.016589 & 0.012394 & 1.338519 & 0.2055 \\
\hline NPF & -0.113944 & 0.218056 & -0.522543 & 0.6108 \\
\hline BOPO & -0.045831 & 0.011404 & -4.018883 & $0.0017^{*}$ \\
\hline LN SIZE & -2.339107 & 0.014479 & -161.550463 & $0.0000^{*}$ \\
\hline CointEq(-1) & -0.766542 & 0.323968 & -2.366102 & 0.0357 \\
\hline
\end{tabular}

Tabel 7 berikut menampilkan hasil estimation jangkapendek ECM. Estimation ECM dari table diatas menampilkan Variable PDB memiliki pengaruh positif significant terhadap ROA. Variable Inflasi memiliki pengaruh positif significant terhadap ROA. Variable CAR tidak memiliki pengaruh significant terhadap ROA. Variable FDR tidak memiliki pengaruh significant terhadap ROA. Variable NPF tidak memiliki pengaruh significant terhadap ROA. Variable BOPO memiliki pengaruh negative significant terhadap ROA. Variabel Size mempunyai pengaruh negative significant terhadap ROA.

\section{Analisis Jangka Panjang ARDL}

Estimasi jangkapanjang yakni hal yang diutamakan dalam pengaplikasian ARDL. Dengan mengaplikasikan ARDL,dapat menelaah hubungan jangkapanjang dikala variable-variable pengungkapan campuran yang bersifat I(1) dan I(0).Estimator ARDL menjadikan koefisien jangkapanjang yang tetap dan estimasi yang dijadikan tetap dengan koefisiet jangkapanjang yang baik tanpa perduli apakah variable-variable penjelas atau regresornya I(0) maupun I(1). Tabel 8 berikut menampilkan hasil estimasi jangkapanjang ARDL.

Tabel 8.

Estimasi Jangka Panjang ARDL

\begin{tabular}{lcccc}
\hline \multicolumn{1}{c}{ Variabel } & Coefficient & Std. Error & t-Statistic & Prob. \\
\hline LN_GDP & 22.075817 & 9.285690 & 2.377402 & $0.0349^{*}$ \\
\hline INFLASI & -0.022185 & 0.064761 & -0.342566 & 0.7379 \\
\hline CAR & -0.102333 & 0.060337 & -1.696029 & 0.1156 \\
\hline FDR & 0.021642 & 0.016257 & 1.331217 & 0.2079 \\
\hline NPF & -0.148647 & 0.230118 & -0.645960 & 0.5305 \\
\hline BOPO & -0.047637 & 0.022080 & -2.157427 & $0.0519^{*}$ \\
\hline LN_SIZE & -5.569932 & 2.345003 & -2.375235 & $0.0351^{*}$ \\
\hline C & -246.824137 & 103.806771 & -2.377727 & 0.0349 \\
\hline *p-value < 0.05. Signifikan pada level 5\% & & \\
Sumber: Data Diolah & & &
\end{tabular}


Estimasi jangkapanjang dari table
diatas menampilkan Variable PDB mempunyai pengaruh positif significant terhadap ROA. Variable Inflasi tidak memiliki pengaruh significant terhadap ROA. Variable CAR tidak memiliki pengaruh significant terhadap ROA. Variable FDR tidak memiliki pengaruh significant terhadap ROA. Variable NPF tidak memikiki pengaruh significant terhadap ROA. Variable BOPO memiliki pengaruh negative significant terhadap ROA. Variabel Size memiliki pengaruh negative significant terhadap ROA.

\section{SIMPULAN}

\section{Kesimpulan}

Penelitiani ini bertujuan untuk mengkaji Pengaruh Ekonomi Makro dan Karakteristik Bank terhadap Profitabilitas Industri Perbankan Syariah. Dalam penelitian ini, penulis mengaplikasikan pendekatan kuantitatif dan memakai figur ARDL (Auto Regressive Distributed Lag). Menurut hasil dari penelitiani ini, karenanya bisa disimpulkan bahwa:

1. PDB berpengaruh positif signifikan pada jangkapendek maupun jangkapanjang terhadap Profitabilitas Industri Perbankan Syariah di Indonesia Periode 2011-2018.

2. Inflasi berpengaruh positif signifikan pada jangkapendek terhadap Profitabilitas Industri Perbankan Syariah di Indonesia Periode 20112018.Namun, Inflasi tidak mempunyai pengaruh pada jangkapanjang terhadap Profitabilitas Industri
Perbankan Syariah di Indonesia Periode 2011-2018

3. CAR tidak berpengaruh signifikan pada jangkapendek maupun jangkapanjang terhadap Profitabilitas Industri Perbankan Syariah di Indonesia Periode 2011 - 2018.

4. FDR tidak mempunyai pengaruh significant pada jangkapendek maupun jangkapanjang terhadap Profitabilitas Industri Perbankan Syariah di Indonesia Periode 20112018.

5. NPF tidak mempunyai pengaruh significant pada jangkapendek maupun jangkapanjang terhadap Profitabilitas Industri Perbankan Syariah di Indonesia Periode 20112018.

6. BOPO mempunyai pengaruh negative significant pada jangkapendek maupun jangka panjang terhadap Profitabilitas Industri Perbankan Syariah di Indonesia Periode 2011-2018.

7. Size mempunyai pengaruh negative significant pada jangkapendek maupun jangkapanjang terhadap Profitabilitas Industri Perbankan Syariah di Indonesia Periode 20112018.

8. PDB, Inlflasi, CAR, FDR, NPF, BOPO, dan size mempunyai kointegrasi dalam jangkapanjang secara simultan terhadap Profitabilitas. Model persamaan pada penelitian sanggup membeberkan $84 \%$ Profitabilitas, walaupun $16 \%$ lainnya dibeberkan 
oleh elemen lain yang tak termasuk dalam penelitian ini.

\section{Saran}

Saran yang disajikan dari inti sari penelitian yakni sebagai berikut:

1. Saran bagi bank syariah

Diinginkan supaya terkait dan pengelola bank syariah senantiasa memandang situasi makro ekonomi yang berfluktuatif dan terus meningkatkan daya kerjanya. Lebih mengefisiensikan rasio BOPO dalam memakai tarif operasionalnya dan meningkatkan tarif operasional, mengamati size dan diimbangi dengan penempatan dalam pemberian pembiayaan yang berpotensi menciptakan profitabilitas.

2. Saran bagi nasabah

Hasil penelitihan ini bisa diwujudkan referensi tentang profitabilitas perbankan syariah di Indonesia sehingga nasabah bisa mengkaji keadaan bank syariah hal yang demikian.

3. Saran bagi peneliti berikutnya

Diinginkan bagi peneliti berikutnya bisa menerapkan sampel yang lebih banyak dan beraneka dari beraneka narasumber yang ada supaya bisa menelaah lebih luas perihal industri perbankan syariah.

\section{DAFTAR PUSTAKA}

Alharbi, Ahmad Thabet. (2017). Determinant of Islamic banks' profitability: International evidence. International Journal of Islamic and Middle Eastern Finance and Management, 10(3), 331-350. DOI:
https://doi.org/10.1108/IMEFM-122015-0161

Abdurrahman dan Ahmad. (2018). Metode penelitian muamalah. Jakarta: Salemba Diniyah.

Ali, Khizer. et. al. (2011). Bank specific and macro economic indicators of profitability empirical evidence from commercial banks Pakistan. International Journal of Business and Sosial Science, 2(6), 235-242.

Almunawwaroh, Medina dan Marliana, Rina. (2018). Pengaruh CAR, NPF dan terhadap profitabilitas bank syariah di Indonesia. Amwaluna: Jurnal Ekonomi dan Kevangan Syariah, 2(1), 1-18.

Boediono. (2004). Ekonomi moneter. Yogyakarta: BPFE.

Dendawijaya, Lukman. (2009). Manajemen perbankan. Jakarta: Penerbit Ghalia Indonesia.

Djamil, Faturrahman. (2012). Penyelesaian pembiayaan bermasalah di bank syariah. Sinar Grafika: Jakarta.

Harahap, Sofyan Syafri. (2009). Teori kritis laporan keuangan. Jakarta: Bumi Aksara. Jumingan.

Haron, Sudin. (2004). Determinant of Islamic Bank Profitability. Global Journal of Finance and Economics, $1(1), 1-22$.

Hasibuan, Drs. H. Malayu S.P. (2007). Dasardasar Perbankan. Jakarta: PT Bumi Askara.

Kasmir. (2012). Analisis laporan keuangan. Jakarta: Rajawali Pers.

Madura, Jeff. (2007). Introduction to business, edisi keempat. Jakarta: Salemba Empat.

Masood, Omar and Muhammad Ashraf. (2012). Bank-spesific and macroeconomics profitability determinants of Islamic banks: The case of different countries. Qualitative Research in Financial Markets, 4(2/3), 255-268. DOI: https://doi.org/10.1108/1755417121 1252565

Nusantara, Ahmad Buyung. (2009). Analisis pengaruh NPL, CAR, LDR dan BOPO terhadap profitabilitas bank. Tesis tidak diterbitkan. Semarang: Universitas Diponegoro. 
Otoritas Jasa Keuangan. (2018). Statistik perbankan syariah. Diakses melalui www.ojk.go.id.

Peraturan Bank Indonesia Nomor: 2/ 8 /PBI/2000.

Rani, Lina Nugraha. (2013). Analisis faktorfaktor yang mempengaruhi non performing financing pada perbankan syariah di Indonesia periode 2003-2013. Tesis tidak diterbitkan. Surabaya: Fakultas Ekonomi dan Bisnis Universitas Airlangga.

Ramlall, I. (2009). Bank-Specific, Industry Specific and Macroeconomic Determinants of Profitability in Taiwanese Banking System: Under Panel Data Estimation. International Research Journal of Finance and Economics, (34), 160167.

Republik Indonesia. Undang-Undang No. 21 Tahun 2008 Tentang Perbankan Syariah.

Rivai dan Andira. (2009). Bank and financial institution management. Jakarta. PT Raja Grafindo Persada.

Riyadi, S. (2006). Banking assets and liability management, edisi ketiga. Jakarta: FE UI.

Sahara, Ayu Yanita. (2013). Analisis pengaruh inflasi, suku bunga BI dan produk domestik bruto terhadap Return On Asset (ROA) bank syariah di Indonesia. Jurnal Ilmiah Mahasiswa UNESA.

Samuelson, Paul A. Dan William D Nordhaus. (2004). IImu makroekonomi, edisi ketujuhbelas. Jakarta: PT Media Global Edukasi.

Sodiq, Amirus. (2015). Pengaruh variabel makro ekonomi terhadap profitabilitas bank syariah di Indonesia periode 2009-2014. Jurnal Bisnis dan Manajemen Islam, 3(2), 343-363.

Sugiyono. (2015). Metode penelitian kuantitatif, kualitatif, dan R\&D. Bandung: Alfabeta.

Sukirno. (2006). Ekonomi pembangunan: Proses, masalah, dan dasar kebijakan. Jakarta: Kencana.

Suryani dan Hendryadi. (2016). Metode riset kuantitatif. Jakarta: PT. Fajar Interpretama Mandiri.

Widyaningrum, L dan Siswantoro, D. (2014). Analysis the Effect of macroeconomic indicators and specific-firm characteristic as determinant profitability of Islamic banks in Asia. Journal Islamic Economic and Busines, 2(2), 85-97.

Zulifiah, Fitri dan Joni Susilowibowo. (2014). Pengaruh inflasi, BI Rate, CAR, NPF, BOPO terhadap profitabilitas bank syariah 2008-2012. Jurnal Ilmiah Mahasiswa UNESA. 